\title{
【特 集：自動車リサイクルの進化】
}

\section{使用済み自動車貿易から見たグローバルな資源の移動}

\author{
布 施 正 暁 *
}

【要 旨】本稿は, 中古車, 中古部品, あるいは二次資源として国際的に取引されている使用済み自動 車に注目する。多種多様な金属材料から構成される使用済み自動車は, 極めて高い資源ポテンシャルを 持つ人工鉱石と見なすことができる。リユースまたはリサイクル目的で国境を越えて取引される使用済 み自動車の資源ポテンシャルを評価することは，各国の自動車リサイクルを検討する上でも重要である。 本稿は，使用済み自動車貿易を通じて生じるグローバルな資源移動を概観するとともに，資源移動から 見えてくる自動車リサイクルの将来像について考察する。

キーワード：自動車，リサイクル，資源散逸，国際資源循環

\section{1. は じめに}

資源管理の面から自動車を見ると，他の製品に抜きん でた重要性を指摘することができる。まず, その単体の 重量があげられる。乗用車で 1 ton 近い重さをもつ。わ れわれの日常生活において，これほど重い製品はあまり 存在しない。表 1 に乗用車の材料組成 ${ }^{1)}$ を示す。表より, 家庭が所有する乗用車 1 台から鉄 $720 \mathrm{~kg}$, アルミニウ ム $76 \mathrm{~kg}$, 銅 $17 \mathrm{~kg}$, 鉛 $10 \mathrm{~kg}$, 亜鉛 $5.1 \mathrm{~kg}$ が回収可能と いえる。同じ家庭のテレビ, パソコンなどの家電製品 1 台 1 台を考えた場合, これほど大量の金属を回収するこ とは不可能である。また, 自動車には近年注目を集めて いるレアメタルも多く利用されている点 ${ }^{2}$ でも重要であ る。エンジン, ボディに使われる特殊鋼材, 冷延鋼材は ニッケル, クロム, モリブデン, ニオブ, バナジウムが 用いられている。自動車触媒にはパラジウム, ロジウム, 白金の使用, ハイブリットカーの然料電池にはリチウム, コバルトなどの使用があげられる。また自動車の電子制 御システムを担う電子部品の特殊機能を発揮させるため にも, 多くのレアメタルが使用されている。以上より, 移動手段としてではなく資源として見た自動車も極めて

原稿受付 2010.2.19

* 独産業技術総合研究所安全科学研究部門 連絡先：テ 305-8569 茨城県つくば市小野川 16-1

E-mail:m-fuse@aist.go.jp
魅力的な存在である。したがって, 使用済み自動車から 効率的に資源を回収する自動車リサイクルシステムの構 築は, 資源の持続可能性を目指す上で重要な命題といえ る。

高い資源ポテンシャルをもつ使用済み自動車は, 同時 に国際商品としての性格も有する。この国際商品性は自 動車リサイクルシステムを考える際に重要な示唆を与え る。自動車本来の価值は消費者に移動サービスを提供す ることにある。ある国で自動車としての価值が評価され なくとも, 他の国でその価值が評価されれば, その自動 車は廃萧されずに中古車としての第 2 のライフサイクル を始める。自動車の補修・交換部品の供給源として, 中 古部品が国際的に利用されることも考えられる。また, 使用済み自動車の高い資源ポテンシャルから, 二次資源 として輸出入されることも十分に考えられる。このよう なリユースあるいはリサイクルを目的とした使用済み自 動車貿易は, 輸出国だけでなく輸入国の自動車リサイク

表 1 乗用車 $(1,500 \mathrm{cc})$ の材料組成

\begin{tabular}{ccc}
\hline 材料 & 構成比率 $(\%)$ & 重量構成 $(\mathrm{kg})$ \\
\hline 鉄 & 71.0 & 725.2 \\
アルミニウム & 7.4 & 76 \\
銅 & 1.6 & 16.8 \\
鉛 & 1.0 & 10.1 \\
亜鉛 & 0.5 & 5.1 \\
その他 & 18.4 & 188 \\
\hline 計 & 100.0 & 1021.2 \\
\hline
\end{tabular}


ル活動に直接的な影響を与える。

本稿では, 使用済み自動車貿易に伴うグローバルな資 源の移動について，筆者が行った研究事例を紹介する。 またグローバルな資源移動から見えてくる自動車リサイ クルの方向性について議論する。

\section{2. 日本からの使用済み自動車輸出に伴う資源 流出}

最初に, 日本からの使用済み自動車の輸出に伴う資源 流出の推計事例 ${ }^{3,4}$ を紹介する。ここで取り扱う日本か ら輸出される使用済み自動車は, 日本で廃棄された後 に海外で中古車, 中古部品, あるいは二次資源として利 用されるものである。貿易統計を用いて, 1988 年から 2005 年における日本からの中古車, 中古部品, 二次資 源輸出量を推計し, 資源組成を乗じて資源流出量を概算 した。ベースメタルである鉄, アルミニウム, 銅, 鉛, 悪鉛に加えて, レアメタルとしてエンジンに使用される マンガン, ニッケル, クロム, モリブデンを対象資源と した。

資源流出量の推計結果を見る前に，そのベースとなる 使用済み自動車輸出量の推計結果について概観する（図 1)。使用済み自動車輸出量は, 1988 年の 73 万 ton から 2005 年の 260 万 ton までに急増している結果が得られ た。輸出に占める中古車, 中古部品の割合が極めて高い ことがわかる。主要な輸出先を見ると, 中古車はロシア,
ニュージーランド, フィリピンなど, 中古部品はアメリ カ, インドネシア, マレーシア, 二次資源は韓国, 台湾, 中国に多く輸出されている。このことから, 中古車, 中 古部品, 二次資源の順に, 近隣国または新興国への輸出 が増加する傾向が確認できる。

以上の 1988 年から 2005 年までの使用済み自動車の輸 出に伴い国外に流出した資源量の集計結果を表 2 に示す。 対象 17 年間において, 国内で廃棄された自動車のベー スメタルのうち, 鉄 1,900 万 ton, アルミニウム 270 万 ton, 銅 23 万 ton, 鉛 38 万 ton, 亜鉛 6.8 万 ton が国内 で回収されずに国外に流出している結果が得られた。エ ンジン由来のレアメタルでは, マンガン 2.2 万 ton, ニッケル 0.43 万 ton, クロム 3.4 万 ton, モリブデン 0.12 万 ton が国外に流出している結果が得られた。

続いて 2005 年に注目して, 資源流出量の推計結果と 対応する資源の国内発生量および二次資源としての直接

表 21988 年から 2005 年までの資源の流出総量

\begin{tabular}{llr}
\hline & \multicolumn{1}{c}{ 資源 } & 流出総量 $($ ton $)$ \\
\hline 使用済み自動車 & 鉄 & $19,000,000$ \\
& アルミニウム & $2,700,000$ \\
& 銅 & 250,000 \\
& 鉛 & 380,000 \\
& 亜鉛 & 68,000 \\
\hline エンジン & マンガン & 22,000 \\
& ニッケル & 4,300 \\
& クロム & 34,000 \\
& モリブデン & 1,200 \\
\hline
\end{tabular}

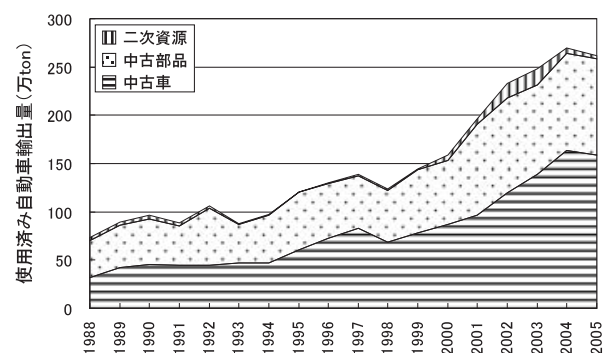

(a) 使用済み自動車

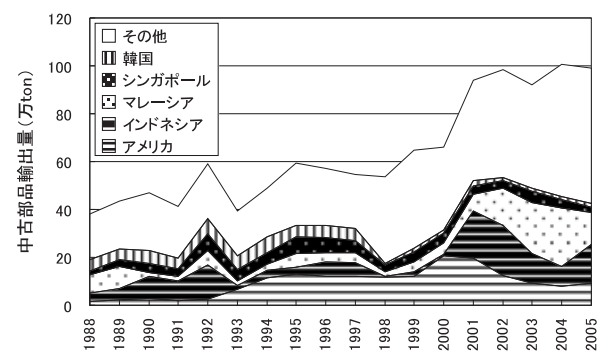

(c) 中古部品

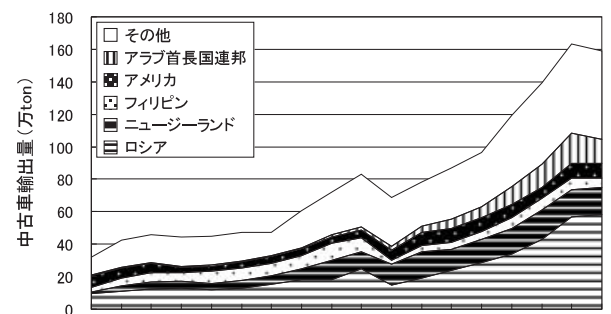

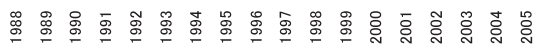
(b) 中古車

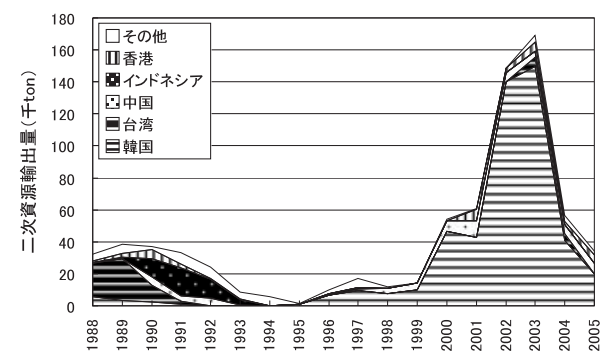

(d) 二次資源

図 1 日本からの使用済み自動車輸出量 
輸出量との比較結果を表 3 に整理した。2005 年におい ては, 鉄 190 万 ton, アルミニウム 25 万 ton, 銅 2.4 万 ton, 鉛 2.7 万 ton, 亜鉛 0.8 万 ton, クロム 0.32 万 ton, マンガン 0.2 万 ton, ニッケル 390 ton, モリブデン 110 ton 流出している結果が得られた。これらの流出量は, 自 動車廃棄に伴い国内で発生した各資源のうち, 鉄 46\%,

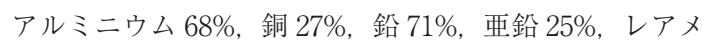
タル $67 \%$ の割合を占めている。二次資源として直接的に 輸出した量と比較すると, アルミニウム, 鉛, 覀鉛, クロ ム, マンガンの流出量は, 2.1 倍から 6.5 倍の值となり, 国全体から見ても無視できない量であることがいえる。

以上の結果は, 使用済み自動車中の有用金属の多くは 国内で回収されずに国外に流出していることを意味して いる。そこで国外に流出した資源のうち, 回収が相対的 に難しい銅, 鉛, 亜鉛, レアメタルを取り上げて, その
回収可能性について検討した。図 2 に対象 17 年間にお ける銅, 鉛, 亜鉛, レアメタルの流出先での蓄積量と, 日本から流出先までの距離と流出先の一人あたり GDP (2005 年の值を使用) の関係を眓示する。このとき, 流 出先までの距離は日本での資源回収を想定した輸送コス 卜（回収コスト），一人あたり GDP は流出先で資源回 収する場合の現地の技術水準の代理指標として用いてい る。ただし，エンジン由来に限定されるレアメタルは, 金属間での傾向が一緒になるため, 合計した結果を示す。 この図の見方として, 流出先までの距離が短く（回収コ ストが低い), 一人あたり GDP が高い（流出先の技術 水準が高い）場所に蓄積量が多く分布する場合, その資 源の回収可能性は高いと判断する。反対の場合は資源散 逸リスクが高いことになる。以上の判断基準に基づいて 図を解釈すると, まず, レアメタルの回収可能性が他の

表 32005 年における資源の流出総量, 国内発生量および直接輸出量

\begin{tabular}{|c|c|c|c|c|c|c|}
\hline & 資源 & 流出総量 (ton): a & 発生量 (ton): b & 直接輸出量 (ton): c & $\mathrm{a} / \mathrm{b}$ & $\mathrm{a} / \mathrm{c}$ \\
\hline \multirow[t]{5}{*}{ 使用済み自動車 } & 鉄 & $1,900,000$ & $4,100,000$ & $5,300,000$ & 0.46 & 0.36 \\
\hline & アルミニウム & 250,000 & 370,000 & 96,000 & 0.68 & 2.60 \\
\hline & 銅 & 24,000 & 89,000 & 420,000 & 0.27 & 0.06 \\
\hline & 鉛 & 27,000 & 38,000 & 8,900 & 0.71 & 3.03 \\
\hline & 覀鉛 & 8,000 & 32,000 & 3,900 & 0.25 & 2.05 \\
\hline \multirow[t]{4}{*}{ エンジン } & マンガン & 2,000 & 3,000 & 1,000 & 0.67 & 2.00 \\
\hline & ニッケル & 390 & 590 & 1,100 & 0.66 & 0.35 \\
\hline & クロム & 3,200 & 4,700 & 490 & 0.68 & 6.53 \\
\hline & モリブデン & 110 & 160 & 90 & 0.69 & 1.22 \\
\hline
\end{tabular}

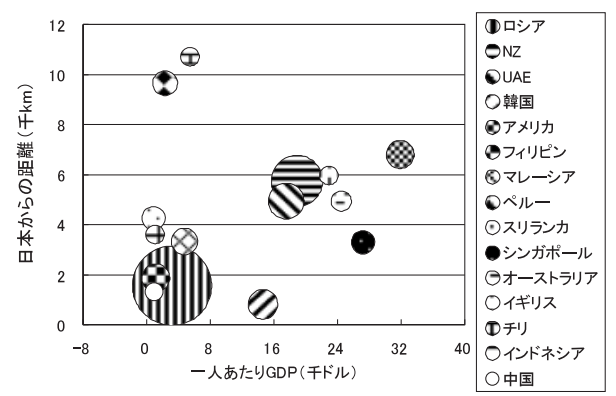

(a) 銅

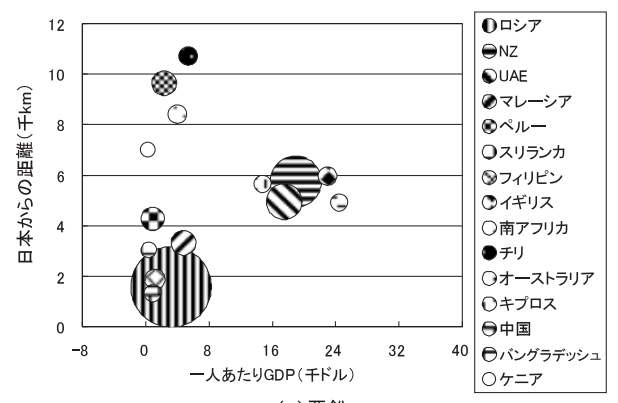

(c) 亜鉛

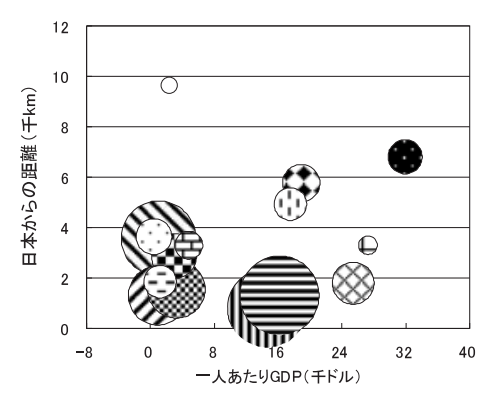

(b) 鉛

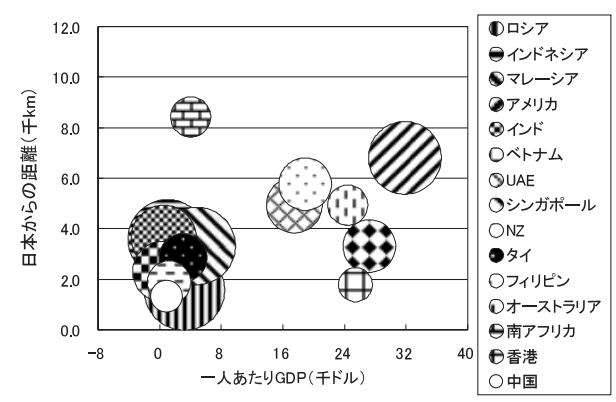

(d)レアメタル

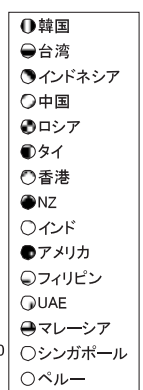

図 2 日本からの資源流出量, 流出距離, 流出先の一人あたり GDP の関係 
金属と比較して高いといえる。続いて, 鉛, 銅, 亜鉛の 順で回収可能性が落ちていく（または資源拡散リスクが 高くなる）傾向がある。ただし, 回収可能性が相対的に 高いレアメタルに関しても，日本からの距離が 3,000 $\mathrm{km}$ 以上, かつ一人あたり GDP が 1 万ドル未満の国が 占める割合は $60 \%$ を超えている。このことから, 使用 済み自動車中の有用金属の資源拡散リスクが高い状況に あるといえる。

\section{3. 中古車貿易に伴うグローバルな資源の移動}

日本からの使用済み自動車輸出を通じて, 大量の資源 が国外に流出している現状が明らかになった。ここでは, 同様の現象が日本だけでなく世界についても言及できる かを検討する。そのため, 各国で発生する使用済み自動 車のうち, 中古車として取引される貿易に注目して, そ の資源移動量を推計した事例 ${ }^{5,6)}$ を紹介する。日本だけ でなく世界を対象とした事例であるため，期間は 2005 年, 車種は乗用車, 資源は鉄, アルミニウム, 銅, 鉛, 亜鉛と推計対象は限られている。

2005 年の中古車輸出量の推計結果を表 4 に示す。表 では中古車輸出における世界上位 10 力国と各国で発生 した使用済み自動車 (ELV) 中の輸出が占める割合を 与える。世界各国で取引される中古車の総数は 410 万台 と推計された。自動車生産国である日本, ドイッ, アメ リカ, 韓国, フランス, イタリア, スペインが主要な中 古車輸出国としてあげられる。日本, ドイッ, 米国の上 位 3 カ国の輸出量は世界貿易の 6 割を占めている。使用 済み自動車中の輸出割合に着目すると, 日本, ドイッ, 韓国, 南アフリカ, スイスは 0.25 から 0.53 までの比較 的に高い值が得られた。このような国では使用済み自動 車の多くは中古車として輸出されるため, 国内での資源 回収可能性は低いと考えられる。

表 42005 年の中古車輸出量

\begin{tabular}{lrrrr}
\hline \multicolumn{1}{c}{ 輸出国 } & $\begin{array}{c}\text { 輸出量 } \\
\text { (万台) }: \mathrm{a}\end{array}$ & $\begin{array}{c}\text { 輸出割合 } \\
(\%)\end{array}$ & $\begin{array}{c}\mathrm{ELV}^{*} \\
\text { (万台) }: \mathrm{b}\end{array}$ & $\mathrm{a} / \mathrm{b}$ \\
\hline 1 日本 & 100 & 24 & 400 & 0.25 \\
2 ドイツ & 90 & 22 & 170 & 0.53 \\
3 アメリカ & 44 & 11 & 790 & 0.06 \\
4 韓国 & 28 & 7 & 54 & 0.52 \\
5 リトアニア & 19 & 5 & 1 & 13.57 \\
6 フランス & 18 & 4 & 170 & 0.11 \\
7 イタリア & 15 & 4 & 260 & 0.06 \\
8 南アフリカ & 14 & 3 & 43 & 0.33 \\
9 スイス & 9 & 2 & 23 & 0.39 \\
10 スペイン & 8 & 2 & 76 & 0.11 \\
その他 & 62 & 15 & & \\
\hline 計 & 410 & 100 & & \\
\hline
\end{tabular}

*：ELVは使用済み自動車の略記である
表 5 に輸入についての推計結果を整理した。ここでは, 主要輸入国の国内市場に中古車輸入が及ぼす影響に注目 する。表より, ロシア, オーストラリア, リトアニア, チェコ, カザフスタンといった資源国または新興国が主 要な輸入国としてあげられる。これらの国において, 国 内市場 (新車販売量十中古車輸入量) に対する中古車の 輸入量の割合は 0.22 から 0.73 の值が得られた。このこ とから, 中古車輸入が国内市場に大きな影響を及ぼして いることがわかる。ドイツ, スペイン, イタリアなどの 自動車生産国も中古車を輸入しているが, 国内市場に占 める割合は 0.1 未満となり, 資源国または新興国ほどの 影響は見られなかった。

2005 年における中古車貿易に伴うグローバルな資源 の移動総量の推計結果を表 6 に示す。 340 万 ton の鉄, 31 万 ton のアルミニウム, 7.5 万 ton の銅, 3.2 万 ton の鉛, 2.7 万 tonの亜鉛が国間を移動している結果が得 られた。ただし, 今回の結果は中古車のうち, 乗用車の みを対象としたものである。たとえば, 図 1 に示される 日本からの使用済み自動車輸出量のなかで乗用車の占め る割合は 3 割にしかすぎない。したがって, 貨物車, バ スなどの他の車種, また中古部品, 二次資源などを考慮 した場合, 資源の移動総量はさらに増大するとことが考 えられる。

続いて, 中古車の世界貿易量の 6 割を占める日本, ド イツ，米国からの資源流出に注目する。ここでは，3カ 国の流出構造を明らかにするため, 図 2 と同様に各流出 先への流出量と各流出先までの距離, 各流出先の一人あ

表 52005 年の中古車輸入量

\begin{tabular}{lcrrr}
\hline \multicolumn{1}{c}{ 輸入国 } & $\begin{array}{c}\text { 輸入量 } \\
\text { (万台) }: \mathrm{a}\end{array}$ & $\begin{array}{c}\text { 輸入割合 } \\
(\%)\end{array}$ & $\begin{array}{c}\text { 新車販売 } \\
(\text { 万台 }): \mathrm{b}\end{array}$ & $\mathrm{a} /(\mathrm{a}+\mathrm{b})$ \\
\hline 1 ロシア & 43 & 10 & 150 & 0.22 \\
2 オーストラリア & 39 & 10 & 59 & 0.40 \\
3 リトアニア & 29 & 7 & 11 & 0.73 \\
$4 \mathrm{NZ}$ & 17 & 4 & 8 & 0.69 \\
5 チエコ & 14 & 3 & 13 & 0.52 \\
6 ドイツ & 13 & 3 & 200 & 0.06 \\
7 カザフスタン & 12 & 3 & n.a & n.a \\
8 UAE & 11 & 3 & n.a & n.a \\
9 スペイン & 10 & 2 & 160 & 0.06 \\
10 イタリア & 10 & 2 & 230 & 0.04 \\
その他 & 212 & 52 & & \\
\hline 計 & 410 & 100 & & \\
\hline
\end{tabular}

表 62005 年の中古車貿易に伴う資源移動総量

\begin{tabular}{lr}
\hline \multicolumn{1}{c}{ 資 源 } & 移動総量 $($ ton $)$ \\
\hline 鉄 & $3,400,000$ \\
アルミニウム & 310,000 \\
銅 & 75,000 \\
鉛 & 32,000 \\
垔鉛 & 27,000 \\
\hline
\end{tabular}


たりGDPの関係を図 3 に示した。日本に関しては,アジ アまたはオセアニア地域の新興国または近隣国に多くの 金属資源を流出している状況が明らかになった。ドイツ の場合, 東ヨーロッパ地域の新興国だけでなく, フラン スといった近隣の先進国にも多くの金属資源が流出して いる。米国は日本, ドイツと異なる流出構造を持ち, 距 離や経済水準に関係なく流出先は幅広く分布している。 日本, ドイッ, 米国について, 流出先の中で低所得国（一 人あたり GDP1 万ドル未満とする）の総流出量に対す る割合は，それぞれ 47\%,58\%,55\% となった。したがっ て, 日本, ドイツ, 米国から中古車輸出を通じて間接的 に大量の金属資源が資源回収される体制の十分に整備さ れていない, または整備途中である国に流出している可 能性が示された。

\section{4. グローバルな資源移動から見える自動車リ サイクルの将来}

2., 3.の事例を大まかに整理すると, 日本, ドイッ, 米国といった自動車生産国から新興国への中古車, 中古 部品, 二次資源輸出を通じて, 大量の資源が移動してい る傾向が明らかになった。また，2.の日本からの使用済 み自動車輸出量の増加傾向と資源の主要な流出先である
新興国の経済発展の可能性から, グローバルな資源の移 動量は今後も拡大すると考えられる。

このような資源移動の現状および将来の動向を前提に して，自動車リサイクルの将来像について考えてみたい。 国際商品性を有する使用済み自動車には, その性格に見 合ったリサイクルシステムを考える必要がある。それは 各国が個別に自動車リサイクルを行う現状の限界を意味 する。たとえば, 自動車生産国では今後使用済み自動車 の輸出量が増加し, 国内での解体処理量は減少すること が予想される。結果として, 破砕工程を経て生じる自動 車シュレッダーダストのような最終廃棄物は減少する一 方で, 国内のリサイクル施設の稼動率および資源回収量 も減少することになる。またレアメタル回収のための先 端技術開発も使用済み自動車自体の回収が困難になるこ とで十分な効果を得られない可能性が生じる。特に日本 の場合, 他国に先駆けて整備した自動車リサイクル法, リサイクル技術，リサイクル施設を十分に活用できない 状況が考えられる。一方, 輸出される使用済み自動車の 主な利用先は, 自動車リサイクルに関する法制度, 技術, 施設といった基本的な体制が十分に整備されてない，も しくは整備途中である新興国である。このような国で効 率的に資源を回収することは困難である。

グローバルな資源移動を想定した場合の自動車リサイ

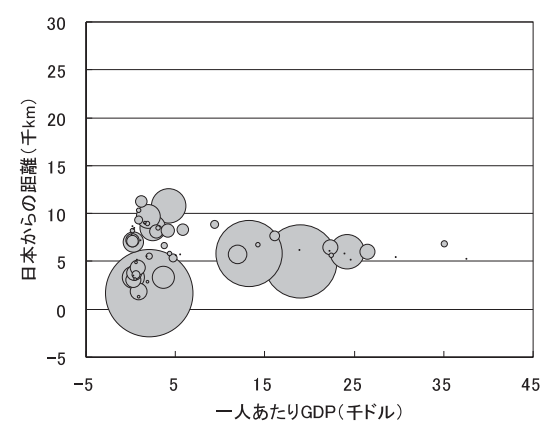

(a) 日本からの資源流出

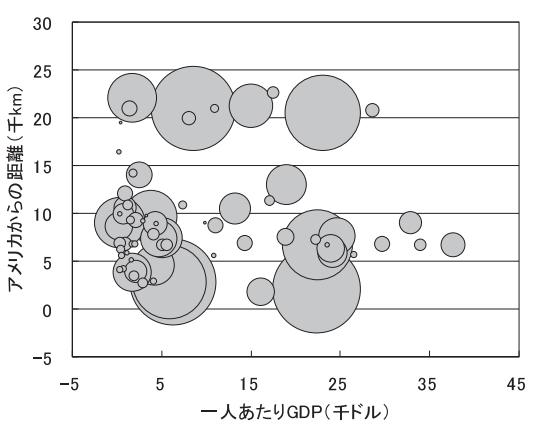

(c)アメリカからの資源流出

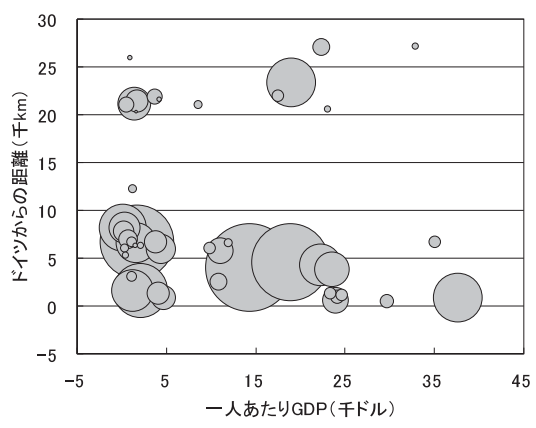

(b)ドイツからの資源流出

図 3 日本, ドイッ, アメリカからの資源流出量, 流出距離, 流出先の一人あたり GDP の関係 
クルの方向性として，2つのシナリオが考えられる。一 つは資源移動を制御するシナリオである。中古車, 中古 部品, 二次資源輸出を禁止するまたは制約することで, 当該国内で発生した使用済み自動車をすべて当該国内で リサイクルする考え方である（個別リサイクルと呼ぶこ とにする)。もう一つのシナリオは, 資源移動の存在を 認め, 関係国が協力して最適なリサイクルシステムを導 入する考え方である（広域リサイクルと呼ぶ）。この場 合，法制度および技術開発において先導する輸出国が輸 入国に制度設計のノウハウおよび関連技術を移転する ケース（広域リサイクル 1)，またリサイクル能力が高 い輸出国に輸入国の使用済み自動車を再輸出して集中的 にリサイクルするケース（広域リサイクル2）など, 状 況に応じた選択肢が考えられる。

筆者は日本と夕イを対象にして，産業連関分析を用い て個別リサイクルおよび広域リサイクルに関するシナリ 才評価を行った ${ }^{7)}$ 。図 4 に, 日本から夕イへの使用済み 自動車輸出を禁止し，日本国内でリサイクルするシナリ オ（個別リサイクル，輸出の存在を認め, 代わりにタ イヘリサイクル技術を移転するシナリオ（広域リサイク ル 1), 夕イの使用済み自動車を日本でリサイクルする シナリオ（広域リサイクル 2）について, 現状に対する ライフサイクル $\mathrm{CO}_{2}$ 排出量の増減を示した。新たな資 源の投入が必要となる個別リサイクルより広域リサイク ルのほうが, $\mathrm{CO}_{2}$ 削減に効果的であるという結果が得 られた。このシナリオ評価では, 使用済み自動車を通じ て新車や新品部品より中古車や中古部品を安価に手に入 れることのできる便益を考慮していない。このような中 古品貿易が輸入国にもたらす生活の質の向上効果 ${ }^{8)}$ も考

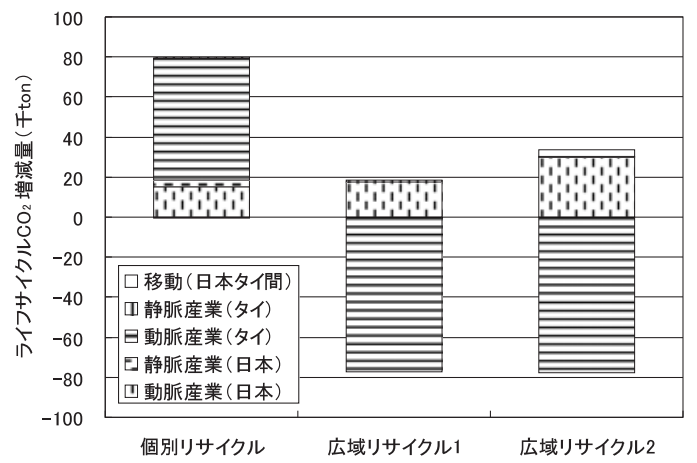

図 4 日本とタイを対象にした自動車リサイクルシナリ オのライフサイクル $\mathrm{CO}_{2}$ 評価
えると, 広域リサイクルのシナリオが今後の自動車リサ イクルの進むべき将来像といえる。

\section{5.おわりに}

移動手段としてわれわれの生活に欠かすことのできな い自動車は，潜在的な資源としても魅力的な存在である。 本稿では, 自動車生産国内で廃亲された自動車の多くは, 中古車, 中古部品あるいは二次資源として新興国を中心 に国際的に利用されている現状を紹介した。このような 使用済み自動車貿易に伴い生じるグローバルな資源の移 動は，現状および将来の資源散逸のリスクを示唆するも のである。今後の自動車リサイクルのあり方として, グ ローバルな資源の移動を前提としつつ，輸出国と輸入国 が協力しながら地球全体としての資源散逸リスクを低減 させる最適解を探求する取り組みが重要である。

\section{参 考文 献}

1）河西純一，山戸昌子：LCA の自動車業界での取り組み, 自動車技術，第 56 巻，第 7 号，pp. 64-69（2002）

2）原田幸明：レアメタル類の使用状況と需給見通し, 廃 棄物循環学会誌，第 20 卷，第 2 号, pp. 49-58（2009）

3）布施正暁, 鹿島 茂：日本からの使用済み自動車輸出量 の推計, 廃棄物学会論文誌, 第 18 巻, 第 5 号, pp. 305313 (2007)

$4)$ M. Fuse, K. Nakajima and H. Yagita: Outflow of Resources from Japan Focusing on End-of-life Vehicles, Materials Transactions, Vol. 48, No.9, pp. 2436-2444 (2007)

$5)$ M. Fuse, H. Kosaka and S. Kashima: Estimation of World Trade for Used Automobiles, Journal of Material Cycles and Waste Management, Vol. 11, No. 4, pp. 348357 (2009)

6 ) M. Fuse, K. Nakajima and H. Yagita: Global Flow of Metal Resources in the Used Automobile Trade, Materials Transactions, Vol.50, No.4, pp. 703-710 (2009)

7 ) M. Fuse and S. Kashima: Evaluation Method of Automobile Recycling Systems for Asia Considering International Material Cycles, Journal of Material Cycles and Waste Management, Vol. 10, No. 2, pp. 153-164（2008）

8) E. Williams, R. Kahhat, B. Allenby, E. Kavazanjian, J. Kim and M. Xu : Environmental, Social, and Economic Implications of Global Reuse and Recycling of Personal Computers, Environmental Science and Technology, Vol. 42, pp. 6446-6454 (2008) 


\title{
Global Resource Cycles in End-of-life Vehicle Trade
}

\author{
Masaaki Fuse \\ Research Institute of Science for Safety and Sustainability, National Institute \\ of Advanced Industrial Science and Technology (AIST) \\ (16-1 Onogawa, Tsukuba, Ibaraki 305-8569 Japan)
}

\begin{abstract}
This work focuses on end-of-life vehicles being traded internationally for reuse or recycling. End-of-life vehicles are comprised of a large range of metal types that can be identified as artificial ores with high resource potentials. It is important to take into consideration the recycling system for evaluating the resource potential of traded end-of-life vehicles when designing new automobiles. In this paper, we give an overview of global resource cycles in end-of-life vehicle trade and discuss the future of automobile recycling systems.
\end{abstract}

Key words : automobiles, recycling, resource losses, global resource cycles 